\title{
Advancing Gallaudet: Alumni Support for the Nation's University for the Deaf and Hard-of-hearing and its Similarities to Black Colleges and Universities
}

Received (in revised form): May 17, 2005

\section{Noah D. Drezner}

Noah D. Drezner is a Ph.D. student in higher education in the Policy, Management, and Evaluation Division at the University of Pennsylvania Graduate School of Education in Philadelphia. He currently holds degrees from the University of Rochester (B.S.) and the University of Pennsylvania (M.S.Ed.) His research interests include philanthropy within both majority and minority serving institutions. Before returning to graduate school Mr. Drezner was a development officer at the University of Rochester.

\begin{abstract}
Gallaudet University, originally chartered by the US Congress as the Columbia Institute for the Deaf and Dumb and Blind in 1864, recently began to solicit donations from their alumni through formal fund-raising campaigns. Using a combination of historical and qualitative analysis coupled with descriptive statistics from institutional data and the Voluntary Support of Education Survey, Gallaudet's advancement story becomes apparent. Working within the Deaf culture and its nontraditional view of philanthropy, Gallaudet's fund-raising experiences and results are similar to those of historically black colleges and universities.
\end{abstract}

Author's Contact Address:

Noah D. Drezner

University of Pennsylvania Graduate School of Education 3700 Walnut Street

Philadelphia, PA 19104, USA

Phone: +1 2158986646

Fax: +1215 5736069

Email: ndrezner@gse.upenn.edu
Keywords:

Deaf education, fund raising, $H B C U$ s

\section{Introduction}

John Havens and Paul Schervish note that over the next 55 years America will experience a "great wealth transfer" where $\$ 41$ trillion will likely be passed on from one generation to the next-through bequest, philanthropy, and taxes. A conservative estimate by Havens and Schervish approximates that of the "great wealth transfer" 15 percent, or $\$ 6$ trillion, will be given to nonprofit organizations. ${ }^{1}$ Havens and Schervish conducted their study in 1999 before the Bush tax cuts that propose an elimination of estate taxes and the tax advantage for charitable giving at death. It is unclear how the $\$ 6$ trillion estimate will be affected if the tax cuts are adopted permanently. David Joulfaian, from the US Treasury Department, found that the estate tax deduction given for charitable bequests is "budget efficient," in that it encourages 
giving at a rate higher than the revenue lost by the government. Joulfaian estimates in the absence of the estate tax, charitable bequests might decline by 12 percent. However, Stuart Butler, vice-president of domestic and economic policy studies at the Heritage Foundation, citing Milton Friedman's permanent income/overlapping generations theory, where a person's residual wealth, after heirs are taken care of, goes to philanthropic causes, believes that by eliminating the estate tax charitable bequests will increase since the "after-tax cost of planned contributions to heirs would be reduced.",2)

As philanthropic organizations and foundations prepare for this phenomenon, many have focused their interests on learning more about traditions of giving outside of the majority communities. Scholars and foundations have concentrated their research efforts on ethnic minorities, women, and religions, but have not studied those populations with differing abilities. ${ }^{3}$ For instance, these reports and studies have neglected to look at the uniqueness of the American Deaf community, its role in giving, and its own culture of philanthropy. ${ }^{4}$ In an era of decreased Federal support of higher education and higher cost of education, Gallaudet University has turned to its graduate deaf alumni to cover the institution's budget differential in a concerted effort recently for the first time. Gallaudet's first formal capital campaign began in 1997.

This paper will examine formal fund raising at Gallaudet University, explore the culture of giving within the Deaf community, and finally draw out the similarities between Gallaudet's development story with other minority communities, specifically, historically black colleges and universities.

\section{Methods}

Both oral histories and primary document analyses were used in this study. Oral histories were gathered by informational interviews and electronic correspondences through "conversation[s] with a purpose." ${ }^{, 5}$ The intention of these communications was to obtain information that was not otherwise available through written documents, policies, or records of Gallaudet University's institutional advancement office. $^{6}$ A "mix of more- and lessstructured questions" were used in semistructured interviews and emails. ${ }^{7}$ The queries in the protocol were intended to be open-ended, conversational, and "guided by a list of questions," yet flexible. ${ }^{8}$ They were hypothetical, ideal position, interpretive as well as exploratory in nature. ${ }^{9}$ Interviews, where permission was granted, were audiotaped, transcribed, and additional notes were taken throughout the interview. Detailed notes of interviews that were not taped were taken as well. American Sign Language (ASL) interpreters were used to facilitate discussion with deaf interviewees where the author's ASL knowledge was not adequate. The transcriptions, notes, institutional records, and archival documents, from Gallaudet University and the Library of Congress, are the dataset for this historical study. ${ }^{10}$ Finally, the dataset was analyzed for content. ${ }^{11}$

\section{History and Context}

In order to educate the deaf, residential schools were opened throughout the United States. In the early portion of 1857 Amos Kendall and others convinced the US Congress to incorporate the Columbia 
Institution for the Instruction for the Deaf, Dumb, and Blind. ${ }^{12}$ Congress began its financial connection to the education of the deaf from day one. The legislature appropriated $\$ 150$ per year for local children attending the school in order to cover their maintenance and tuition costs. ${ }^{13}$ Additional support for the newly established school came from its founder. Kendall donated a house and two acres of land, and finances to cover the start-up costs and salary of the superintendent. ${ }^{14}$ Kendall's wealth and influence undoubtedly helped the then Columbia Institute gain favor in the Congress and within the Jackson administration's eyes. Kendall was a political powerhouse of sorts. He had for six years served as the fourth auditor of the United States Treasury and was Postmaster General for five years. This influence was captured in an 1860 report in The Washington Evening Star: "At that time, next to [President Andrew] Jackson, [Kendall's] mind was the controlling one in the Government, stamping the impress of its patriotism and will more indelibly upon the future of the United States than those of all the rest of Jackson's advisors."

It was this influence that led to the inception of the Columbia Institution for the Deaf and Dumb as a college, in 1864. The college was later renamed after its first president Edward Miner Gallaudet and has received the vast majority of its operating budget from the Federal government. ${ }^{16}$ The government funding was put in place because the institution was given collegial powers, including the ability to confer degrees, by an Act of Congress-that after some debate passed unanimously by the Senate-and was signed by President Lincoln on April 8, 1864. ${ }^{17}$ Upon passing the authorization Congress allocated $\$ 26,000$ to cover the cost of purchasing an additional 13 acres of land. \$26,000 was nearly 400 percent of the Institution's total receipts for its first year of operation $(\$ 6,513.25$; $\$ 5,263.25$ from Congress and $\$ 1,250$ from private subscriptions). ${ }^{18}$

Edward Gallaudet, reflecting on the government's involvement, later pointed out in a speech given to the Columbia Historical Society in 1911 that it was a unique show of support and investment to deaf education that Congress acted "in providing for a national college for the Deaf at a time when the burdens of [the Civil War] were pressing heavily upon the Government." Gallaudet continues by pointing out that the very day that the $\$ 26,000$ of support was "drawn from the Treasury, all communication, either by rail or telegraph, between the Capitol and the country was cut off by the operations of the Civil War." ${ }^{\text {"19 }}$ While this action was indeed significant, that monies were allocated during the war effort to support the creation of a college for the deaf, it is important to note that because of the succession of 11 states from the Union, the true voice of the nation was not part of this decision.

Upon Kendall's death in 1869, only a few months after the College held its first graduation, his estate sold the adjoining 81 acres of land to the institution for $\$ 85,000$; the campus was now a full 100 acres. ${ }^{20}$ The larger campus allowed for expansion and construction. At a January 29, 1871 dedication of Chapel Hall, US President Ulysses S. Grant and then General James A. Garfield spoke about the "courage of the government" to fund the institution while the Country was at war with itself. ${ }^{21}$ Gallaudet quoted Garfield as saying: "Congress took half a million dollars from the public Treasury and devoted it to this work-I hailed it as a nobler expression of the faith and virtue of the American people, and of the 
statesmanship of their representatives, than I ever before witnessed.",22

Garfield continued this "noble expression" himself. The future US President had a continued interest in the College and its progress for the last 15 years of his life. One of Garfield's greatest accomplishments on behalf of the institution was securing the funds for the purchase of the portion of the Kendall estate. Garfield helped raise $\$ 10,000$ from private subscriptions and successfully lobbied Congress for the remaining $\$ 70,000$. $^{23}$

As a result of this Congressional relationship, Gallaudet's situation, throughout its history and still today, closely resembled that of a service academy. In addition to Federal funding of the operating budget, students received Congressional appointments for study, diplomas hold the signature of the President of the United States in the position of Patron of the University, and the Federal General Services Administration is given the task of building the campus. ${ }^{24}$

However, Congressional support of the College was not always as strong as it was under Kendall and Gallaudet. During the College's second president's tenure (Percival Hall 1910-45) Federal support fell amid two world wars and the Depression. Congress, which supported the College generously during the war between the states, was hesitant to fund building and at times even debated whether to continue the school or not. ${ }^{25}$ This decreased funding made it difficult to expand the enrollment, faculty, curriculum, and physical plant. As a result, President Hall considered approaching others for private funding. Nina Van Oss reported this contemplation in the Gallaudet Alumni Bulletin: "He [President Hall] felt that if the alumni could in some way interest the Ford, Rockefeller, Carnegie or such foundations in the College and obtain grants to the College funds for expanding the curriculum, research, and the like, as is done for other noteworthy and deserving institutions, then much progress could be made ... ."26 That alumni were thought of first as those who could help connect the institution to the foundations rather than as a form of support is evidence of the administration's acknowledgement that their deaf alumni were not in a real position to support the institution. This fund-raising reliance on corporations and foundations is evident today. Alumni only made up 7.27 percent of the total income from private support while corporation and foundation gifts accounted for 5.7 percent and 30.7 percent respectively in fiscal year 2004. ${ }^{27}$

While President Hall never saw this connection to foundations happen, his successor, Leonard Elstad, did help reconnect the institution with Congress. Soon after entering the presidency in 1945, Elstad was told that Gallaudet needed to become accredited by the Middle States Association. The resulting report commended the College on its faculty, students, and strategic plans, but found that the College had inadequate facilities. ${ }^{28}$ Additionally, in 1949 , the United States Office of Education and the Federal Security Agency (FSA), the division of the government that the College reported to at the time, decided to review the College as well. The resulting report, The Federal Government and the Higher Education of the Deaf, was very positive. The study found that the Federal government had an obligation to continue the financing of postsecondary education of the deaf simply because it was not economically possible for states to fund this obligation. The report continued that 


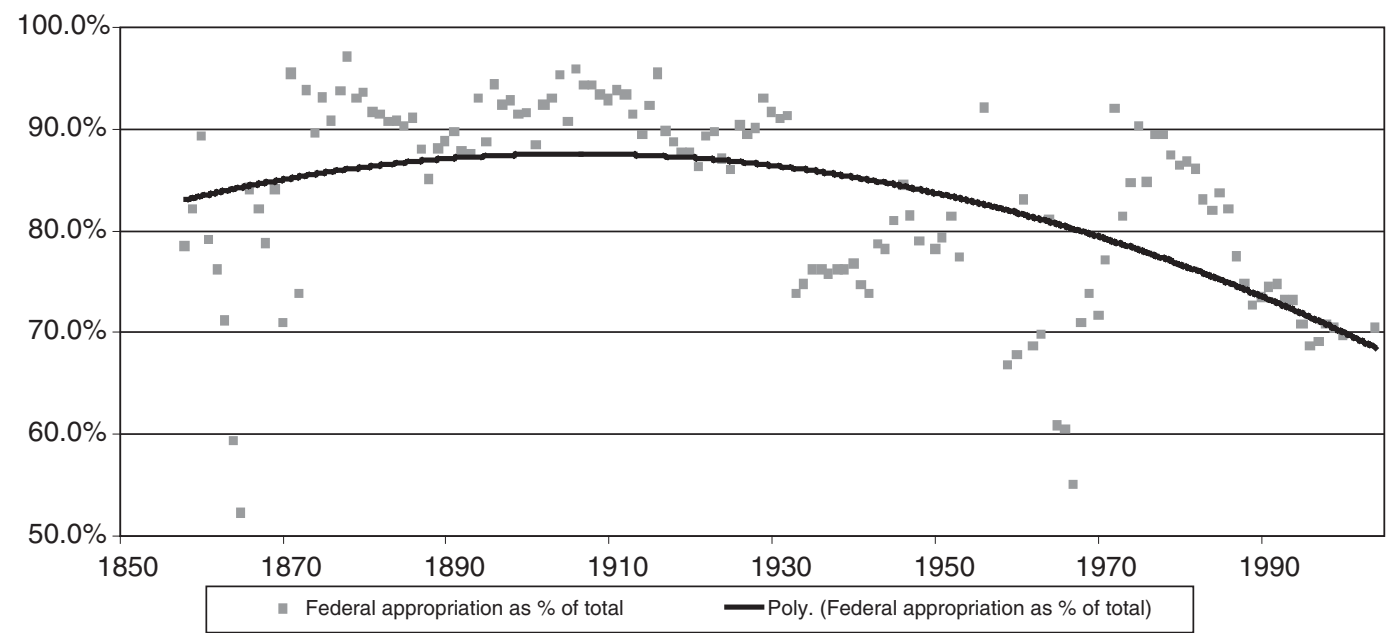

Source: Gallaudet University. Office of Budget, Administration and Finance. Annual Reports of Columbia Institute, Gallaudet College, and Gallaudet University and Congressional Budget Data.

Note: Cost associated with the Model Secondary School for the Deaf and the Kendall Demonstration Elementary School are included in the Federal appropriations. These institutions receive full funding from Congress.

Figure 1: Federal appropriation to Gallaudet as percentage of total budget

in order for Gallaudet to become a firstrate institution a stronger relationship between the government and the institution would be necessary. ${ }^{29}$ In response to the two reports, FSA acting administrator John L. Thurston recommended that Congress and the Bureau of the Budget increase their funding and involvement in the College. ${ }^{30}$ At a May 5, 1954 Congressional hearing, President Elstad used the results of each report to ask for increased support. The result was a new relationship between the Federal government and the College in the passage of Public Law 420 (83rd Congress of the United States). Through Public Law 420, Congress funded increased faculty, curricular development, and improvements to the physical plant. Additionally, the law officially changed the name of the institution to Gallaudet College. One example of the Federal government's increased involvement in Gallaudet was the size of the annual budgets appropriated to the college. In
Elstad's first year, 1945, Congress appropriated $\$ 270,000$. By 1969 , as Elstad left office the Federal appropriation was $\$ 6,900,000 .^{31}$ This was a 1,192 percent increase after accounting for inflation. ${ }^{32}$

The Federal government has only fully or majority supported a small number of institutions, including the military academies, Howard University, and Gallaudet University. States have long supported colleges and universities. ${ }^{33}$ While Congressional support still remains a large source of funding at Gallaudet, Federal support, like with many other government-sponsored programs, has dropped significantly (see Figure 1). In the fiscal year 2000 budget appropriations from Congress only covered 70 percent of the institution's costs. ${ }^{34}$ The Department of Education has asked Gallaudet to be more self-sufficient. Additionally, Congress has given a caveat to its subvention; the institution must keep its tuition at an equivalent level to the land- 
grant institutions. ${ }^{35}$ This hinders

Gallaudet's ability to increase revenues through tuition.

\section{Gallaudet's Fund Raising}

As Federal and state subvention has declined, more and more public and private two- and four-year colleges and universities have started asking for gifts from individual donors. Administrators are searching for all possible nontax revenue sources to help meet budget requirements. Supplemental private dollars "often [provide] the bulk of discretionary income for publicly supported institutions, and hence has been referred to as their margin of excellence." 36 Gallaudet is no different. In order to mend the gap in funding, the University has moved to development. Fund raising, in the past, was not central to the institution as it is at other universities around the United States. Where donations were once used as a margin of excellence Gallaudet now uses them to stay afloat. The current president and first deaf leader of the institution, I. King Jordan, was appointed in 1988, when the University's endowment was only $\$ 5 \mathrm{~m}$. Jordan knew it was time to plan Gallaudet's first formal capital campaign.

However, it was not the institution's first formal campaign; alumni support for Gallaudet did not begin with the institution's first campaign of nearly a decade ago. In 1907, to mark President Gallaudet's 50th anniversary as the institution's executive and his 70th birthday, alumni, without solicitation, announced that they would establish the Edward Miner Gallaudet Fund. The former students left the purpose of the fund open to their honoree's choice. Gallaudet later decided that the fund should be used to finance the library that would bear his name. ${ }^{37}$ Later, in 1919 , alumni raised a total of $\$ 10,000$ in memory of their first president. The money was pledged toward the building of College Hall, a comprehensive administration building that included the president's office, faculty offices, storerooms, the library, an auditorium, alumni office, and a men's residence. ${ }^{38}$

Additionally, in the early 1960s a selfmotivated alumnus, Dave Piekoff, began a centennial campaign with his wife that ended in the purchase, renovation, and endowment of an alumni house-now bearing his name-and the establishment of two additional permanent endowments: the Laurent Clerc Cultural Fund and Graduate Fellowship Fund. Piekoff raised $\$ 1 \mathrm{~m}$ from fellow alumni by traveling the nation and asking for their support for Gallaudet in honor of its significant anniversary. ${ }^{39}$

The golden age in American higher education, when Federal money was abundant, enrollments were on the rise, and large sums of money were spent on institutions' physical plants, lasted for the decades following the Second World War. ${ }^{40}$ However, this golden age ended in the 1970s and 1980s when Federal funds were not as readily available as they once were due to the increases in Federal deficits. As a result many small private liberal arts institutions, such as Gallaudet, began to engage in professionally conducted advancement efforts in the decade of the 1980s. ${ }^{41}$

Historically, there was a development discussion on campus, prior to the 1988 "Deaf President Now" protests, which brought the institution's current president, I. King Jordan on campus. These deliberations focused on what the fund-raising message of the college should be. There was a segment of the administration that thought that the message should be one of charity-that 
giving to Gallaudet was an action of social justice. Another view, and the one that is currently in place, is that giving to Gallaudet is a philanthropic act of supporting higher education, just as it is at any other institution. ${ }^{42}$ This debate over the approach of fund raising, within the rest of higher education, ended in the last 100 years. Early colleges with religious backgrounds appealed to prospects through a charitable lens-donors should give to the disadvantaged. However, around the turn of the century, institutions began to appeal to donors with a philanthropic approach. ${ }^{43}$ Even though discussions took place in the 1980s, Gallaudet did not formalize its development activities until 1990, shortly after President Jordan came to Gallaudet. ${ }^{44}$

The institution hired Grenzebach Glier \& Associates, Inc., a philanthropic management-consulting firm known for its work within higher education, to conduct a campaign feasibility study in 1990. Grenzebach's report informed Gallaudet that, in their infancy with respect to development, they were not ready to proceed with a campaign. The consultants found that, at the time, the Board of Trustees was not committed to the pursuit of private support; Gallaudet's was not yet raising enough funds annually compared with its peers; the institution's cost for dollar raised was too high (27\%); and that their case for support was not clearly articulated. ${ }^{45}$ Over the next seven years Gallaudet's development staff grew and became more experienced and worked to resolve the list concerns presented in the 1990 Grenzebach report.

Gallaudet's first formal campaign was launched in January 1997 without the commission of another feasibility study. The development office and president believed that they had accomplished all of the tasks identified by the Grenzebach report and therefore were ready to proceed with a campaign. ${ }^{46}$ They were. The campaign opened publicly with a goal of $\$ 30 \mathrm{~m}$ and closed five years later nearly $\$ 10 \mathrm{~m}$ above the goal. From initial data most of the success was due to corporate and foundation support and only a small percentage was from alumni. At its height alumni participation in the campaign reached only 15 percent, a low figure for traditional annual funds at private liberal arts colleges that historically reach 33 percent alumni participation, let alone during a capital campaign. ${ }^{47}$ As a result in part of the campaign Gallaudet's endowment, at the end of fiscal year 2003, was $\$ 115 \mathrm{~m}$. ${ }^{48}$

Cathy Sweet-Windham, Gallaudet's executive director of institutional advancement, recognizes that "Gallaudet does not have a long history of philanthropy." As a result of the current state of Federal budgeting "the Federal government is looking more closely at how [the institution is] fund raising and making sure that we are receiving a substantial amount [from fund raising]." Therefore, Gallaudet has identified the need to engage its alumni and identify and develop fund-raising strategies that will increase alumni participation within their annual fund, designated, and comprehensive campaigns. ${ }^{50}$ As with many development offices, Gallaudet has recognized difficulties in achieving these goals. Senior advancement officers identify two major roadblocks in their work with Gallaudet alumni. The first-a common misconception of many institutions' alumni-is the myth that the institution does not need support. Gallaudet alumni, like many alumni from historically black colleges and universities (HBCUs), simply believe that their alma mater is strongly funded by the Federal government and 
supplemented by corporations and foundations, and therefore is not in need of alumni support. ${ }^{51}$ The second barrier to increased alumni support and participation, as identified by the Office of Institutional Advancement, is the culture of giving within the Deaf community. ${ }^{52}$

Philanthropy in the United States has historically been viewed through the lens of the wealthy-white-hearing-man. ${ }^{53}$

Marybeth Gasman and Sibby Anderson Thompkins, who studied fund raising at HBCUs, suggest that when looking at the culture of giving in the African American community the traditional definition of philanthropy is too narrow. ${ }^{54}$ This is the case when looking at giving in the Deaf community as well.

Director of Development Lynne Murray believes that the Deaf community's culture of giving is not one of monetary philanthropy because of historic aspects of the community. Based on her work with Gallaudet alumni, she contends that participation and dollars received are both low for three reasons. The first is that historically deaf adults do not have access to well-paying jobs and therefore do not have the disposable income to donate. The second is that members of the Deaf community are "used to receiving instead of giving." 55 The final reason is that the idea of giving is not passed down within families. Ninety percent of members of the Deaf community have hearing parents. ${ }^{56}$ Additionally, the vast majority of deaf elementary and secondary students attend residential schools. ${ }^{57}$ Sweet-Windham believes that communication barriers between hearing parents and deaf children, as well as the fact that most deaf children do not regularly see their parents give donations due to them living away from home, affects the ability for a culture of philanthropy to flourish in the Deaf community. ${ }^{58}$

Gallaudet's Office of Institutional

Advancement has realized that in order to teach a culture of giving-one that goes beyond monetary giving-it is important to begin at the youngest age possible. ${ }^{59}$ Through Gallaudet University's residential schools, the Kendall Demonstration Elementary School and the Model Secondary School for the Deaf, the Office of Institutional Advancement has begun to teach the importance of volunteerism and community service as forms of philanthropy. Elementary school students participate in activities centered on the University's Campus Community Campaign, which successfully raises funds from nearly half of the institution's faculty and staff. Interestingly the development office finds equal support and participation from hearing and deaf faculty and staff in the Campus Community Campaign. Lynne Murray believes that this might be partially due to Gallaudet's faculty and staff being well compensated. ${ }^{60}$

Realizing that "developing a lifelong relationship with alumni can't be magically turned on as your graduating seniors cross the bridge between their lives as students and their lives as alumni,"61 Gallaudet has begun to work with its college students. In addition to celebrating the importance of philanthropy with precollege students, the importance of cultivating the next generation of donors and philanthropists has led the development office to team with alumni affairs to begin traditional student and young alumni advancement programs in the past year, including senior class gift drives and young alumni targeted events. ${ }^{62}$

The advancement office realizes the importance of having deaf development officers and volunteers. Currently, there is 
only one deaf fund raiser on staff at Gallaudet. In order to increase this number the institution realizes that it needs to "grow its own." ${ }^{\text {" In }}$ order to continue to teach about philanthropy, and more specifically about development, the advancement office recently has begun two internships with students, one from the Model Secondary School and another from the graduate school. The hope is that these students consider a job within Gallaudet's development office in the future. ${ }^{64}$

\section{Deaf Higher Education and its Similarities to HBCUs}

Much like HBCUs, Gallaudet University was established to serve a section of the population that was excluded from traditional American higher education. Deaf students were almost fully relegated to deaf-serving institutions, such as Gallaudet and the National Technical Institute for the Deaf (NTID) at the
Rochester Institute of Technology, until the passage of the Education of the Deaf Act of 1986 (EDA), its amendments, and the Americans with Disabilities Act of 1990 (ADA). The EDA (which officially changed the name of Gallaudet College to Gallaudet University), and even more so the ADA, opened the door for deaf students to attend any institution of higher education in the country, requiring the institutions to provide interpreters and other needed facilities for deaf students should they attend.

The similarities between Gallaudet and HBCUs go well beyond those of their origin and necessity; they are peers with respect to development and fund raising as well. For example, alumni participation in FY 2004 at HBCUs averaged 7.8 percent, while at Gallaudet in the same year participation reached 7.6 percent, both well below the national average for FY 2004 of 21.2 percent. $^{65}$ Gallaudet has closely resembled HBCUs' alumni

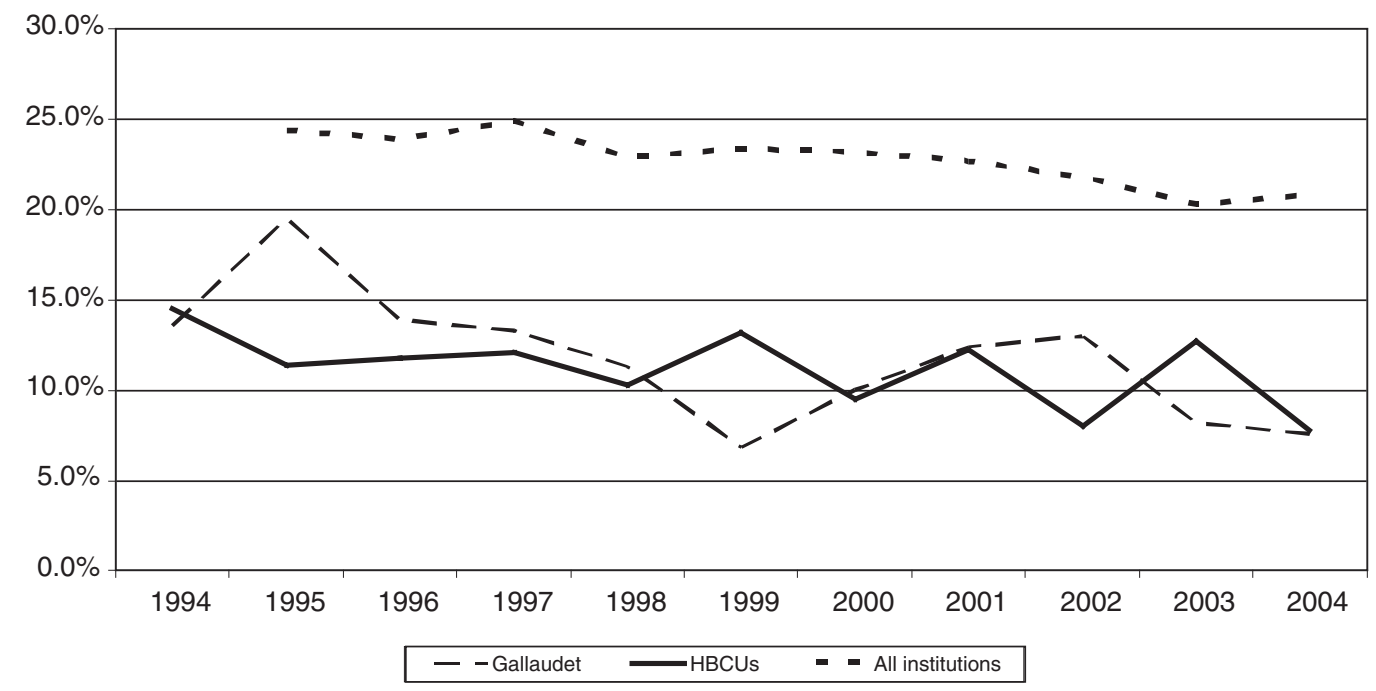

Source: Voluntary Support of Education Survey, Council for Aid to Education, New York Note: Reliable data for 1994 not available.

Figure 2: Alumni donors as percentage of total budget 


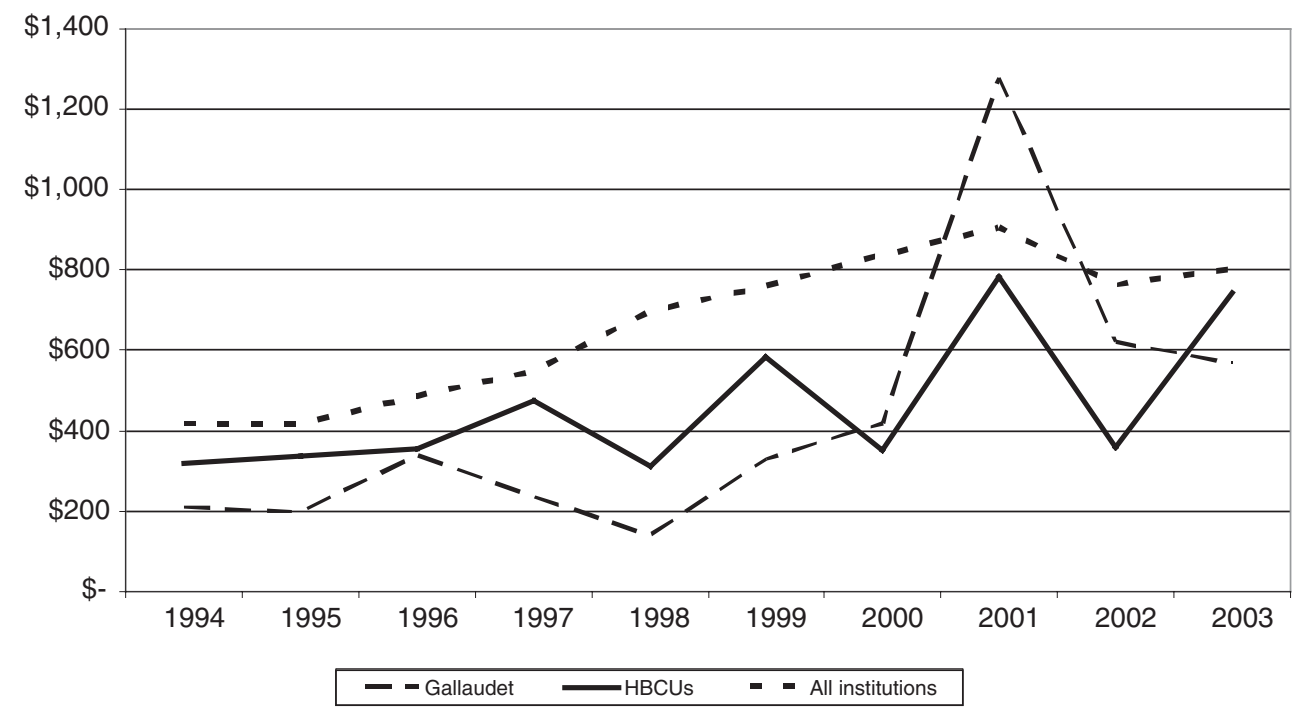

Source: Voluntary Support of Education Survey, Council for Aid to Education, New York

Figure 3: Average alumni gift

participation for at least the past 10 years-consistently being between five and ten percentage points below the national average (see Figure 2).
Additionally, the average alumni gift (see Figure 3) and alumni support per student (see Figure 4) were comparable over the last 10 years as well, with each

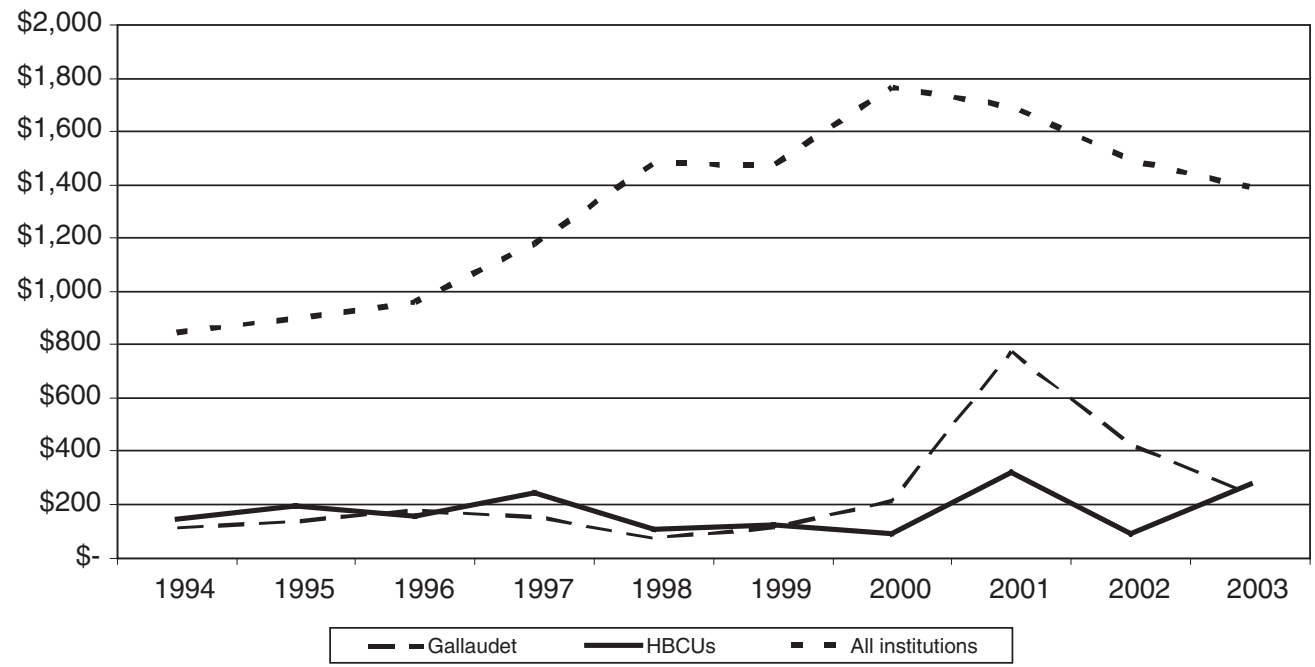

Source: Voluntary Support of Education Survey, Council for Aid to Education, New York

Figure 4: Alumni support per student 
also below the national average.

Gallaudet's average alumni gift surpassed the national average in FY 2001 at the height of its last campaign. Interestingly both HBCUs and Gallaudet experience inconsistent average gifts (indicated by the peak and valley nature of the graph) while the national average shows a much more consistent and increasing average alumni gift. The decrease between FY 2001 and FY 2002 can be explained by the shift of donor dollars after the September 11, 2001 terrorist attacks. The AAFRC found that nonprofit organizations, such as Gallaudet, in the cities that were attacked on September 11, 2001, were affected most by the shift of donor funding. Giving USA reports that nonprofits in Washington, DC had difficulty raising funds for the six months after the attacks. The obstacles to fund raising are attributed in part to the canceling of special events and mailings, as well as the increased expense for direct mailings associated with the treatment of mail by radiation in response to the threat of anthrax. $^{66}$

Foundation support as a percentage of the total giving (see Figure 5) between Gallaudet and HBCUs-the proposed comparison group-was equivalent in the same 10-year period, save fiscal year 1997, where Gallaudet's foundation support reached 68.8 percent while the HBCUs were 19.7 percent. $^{67}$ The 1997 outlier could be explained by the fact that this was the first year of Gallaudet's capital campaign and foundation support increased for that reason. It is interesting to note that, for both Gallaudet and HBCUs, foundation support as a percentage of total dollars raised is higher than that of the national average.

Therefore, it is reasonable to infer that Gallaudet and HBCUs rely on foundation support more than the average higher education institution. This is of concern since the data indicates that FY 2002 and 2003 (the latest data available) marked a point where foundation giving

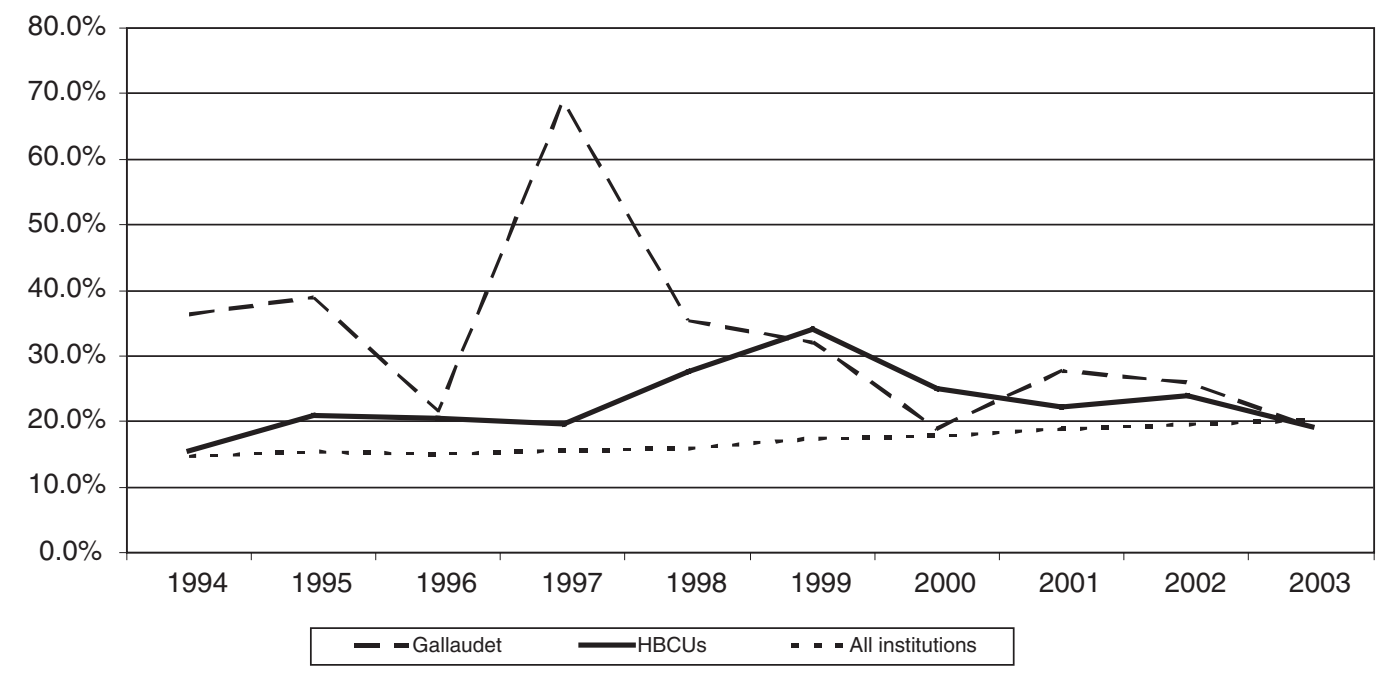

Source: Voluntary Support of Education Survey, Council for Aid to Education, New York

Figure 5: Foundation giving as percentage of total 
toward Gallaudet and HBCUs was on a decline and was about to level out or even dip beneath the national average.

\section{Recommendations}

Kim Kein found that historically, within the private sector, individuals donate most of the money given to the third sector. ${ }^{68}$ Within higher education those individuals that give the most are alumni of the institutions. ${ }^{69}$ This is not the case at Gallaudet University. Parents and friends of the University combine to account for 83 percent of individual donations, while alumni and faculty/staff lag behind at 12 percent and 5 percent of individual giving respectively. $^{70}$

M. Starita Boyce, in her dissertation, found that HBCUs would need to increase their market effectiveness among individual donors in order to shield themselves from their financial hardships based on decreasing public subsidies and relatively small investments. ${ }^{71}$ Gallaudet, like historically black colleges and universities, is threatened by reductions and changes in funding policies from their traditional sources of funding (e.g., corporations and foundation). ${ }^{72}$ Therefore, it is important that both HBCUs and Gallaudet move to increase their individual donor base.

In order to increase the individual donor base it is essential that Gallaudet consider moving their advancement program forward by implementing the following recommendations. Trust is extremely important to African Americans when considering monetary donations. ${ }^{73}$ This is the case for the Deaf community as well. ${ }^{74}$ A personal relationship between the donor and development officer is essential. Deaf identity is highly important within the Deaf culture. Hearing people, even those allies considered part of the "third culture," have trouble being accepted or trusted by the Deaf community. The "third culture" is a term developed by Bienvenu and Colonomos that describes the four growing populations of hearing allies that have arrived at the fringe of the Deaf community in the past 20 years (a period referred to as the Deaf resurgence): (1) professionals (linguists, teachers, and interpreters); (2) hearing parents of deaf children who are engaged with the Deaf community; (3) hearing people who have learned sign language; (4) children of deaf adults (CODAs). ${ }^{75}$ Deaf donors are more likely to donate to an accepted member of their community, or a revered figure, such as Gallaudet President I. King Jordan, than to an outsider. ${ }^{76}$ It is the personal appeal that leads to the successful attainment of a gift. Therefore, it is important that Gallaudet increase the number of deaf development officers and work closely with engaged deaf alumni in solicitations.

Gallaudet should continue, and perhaps increase, its internship program with students from the graduate school and Model Secondary School for the Deaf. A simple way to increase this program would be to include an undergraduate internship in addition to the high school and graduate school positions.

Since the institution's president is so revered within the Deaf community it is important that Gallaudet be cautious in its approach of highlighting his achievements and successes with deaf higher education. While Dr. Jordan is a powerful fund raiser and a compelling reason to support the University, in preparation for the eventual leadership change, Gallaudet should emphasize the leadership of the institution and its president rather than focusing on the specific individual. It is important to 
show prospective donors that not only the current president is a leader in deaf education but also the president's office in general is one of prestige within the Deaf community.

While educating current alumni about the importance and need for support of deaf education, Gallaudet must continue to teach the importance of philanthropy to its current students-their future alumni. By educating current students, Gallaudet will likely have an easier time gaining alumni participation in the future.

\section{Conclusion}

Gallaudet has a strong and unique history within American higher education, one with great Federal support. As Congressional funding begins to decrease, calls for self-sufficiency are on the horizon. As corporations and foundations change their funding priorities, it is important that Gallaudet begin to look more closely at its alumni as perspective donors to the nation's university for the deaf.

Since Gallaudet is relatively new in the advancement arena and has many similarities to HBCUs, it is important that the University embraces its past and look to its colleagues at the HBCUs who are successful at fund raising to share ideas. The Deaf community, like the African American community and other cultural groups, has its own culture of giving. Gallaudet has the opportunity to educate its alumni and students and become a more successful part of this culture.

\section{References}

1. J. J. Havens and P. G. Schervish (1999), Millionaires and the Millennium: New Estimates of the Forthcoming Wealth Transfer and the Prospects for a Golden Age of Philanthropy, Boston College Social Welfare Research Institute, Boston; J. J. Havens and P. G. Schervish
(2003), "Why the $\$ 41$ trillion wealth transfer estimate is still valid: A review of challenges and questions," The Journal of Gift Planning, 7, 1, pp. 1115.

2. D. Joulfaian (2000), "Estate taxes and charitable bequests by the wealthy," Working Paper 7663, National Bureau of Economic Research, Cambridge, MA; S. M. Butler, "Why the Bush tax cuts are no threat to philanthropy," The Heritage Foundation Backgrounder, 1417, 8 March. Online at <http:// www.heritage.org/Research/Taxes/BG1417.cfm>.

3. B. Smith, S. Shue, J. L. Vest, and J. Villarreal (1999), Philanthropy in Communities of Color, Indiana University Press, Bloomington; Council on Foundations (1999), Cultures of Caring: Philanthropy in Diverse American Communities, Council on Foundations, Washington, DC; W. K. Kellogg Foundation (1999), Emerging Philanthropy in Communities of Color: A Report on Current Trends. W. K. Kellogg Foundation, Battle Creek, MI. Available online at <http://www.wkkf.org/Programming/ RenderRes.aspx?CID=12\&ID=687>

4. P. Ladd (2003), Understanding Deaf Culture: In Search of Deafhood, Multilingual Matters LTD, Tonawanda, NY.

5. L. A. Dexter (1970), Elite and Specialized Interviewing, Northwestern University Press, Evanston, IL, p. 136.

6. S. B. Merriam (1998), Qualitative Research and Case Study Applications in Education: Revised and Expanded from "Case Study Research in Education," Jossey-Bass Publishers, San Francisco.

7. Ibid., p. 73.

8. Ibid., p. 74.

9. A. Strauss, L. Schatzman, R. Bucher, D. Erlich and M. Sobshin (1981), Psychiatric Ideologies and Institutions, 2nd edn., Transaction, New Brunswick, NJ; Merriam (1998), Qualitative Research and Case Study Applications in Education, op. cit.

10. M. Q. Patton (1990), Qualitative Evaluation Methods, 2nd edn. Sage, Thousand Oaks, CA.

11. Merriam (1998), Qualitative Research and Case Study Applications in Education, op. cit.

12. A. W. Attwood (1964), Gallaudet College: Its First One Hundred Years, Gallaudet College, Washington, DC; US Statues at Large 11 (1857): 161.

13. H. O. Bishop (1922), "Where the deaf and mute overcome their handicaps," The National Republican, June 17.

14. Attwood (1964), Gallaudet College, op. cit.

15. Attwood (1964), Gallaudet College, op. cit., p. 4, quoting The Washington Evening Star, 1860; N. B. Tadie (1979), "A history of drama at Gallaudet College: 1864 to 1969 ," Ph.D. Dissertation, New York University, 1979.

16. Attwood (1964), Gallaudet College, op. cit.; John L. Pulley (2003), "The sign language of fund raising. Gallaudet University, an institution founded for the deaf, aims for donors' hearts," The Chronicle of Higher Education, July 11, p. A23. 
17. "An Act to Authorize the Columbia Institute for the Deaf and Dumb and the Blind to Confer Degrees," U.S. Statutes at Large (1864): 45; Attwood (1964), Gallaudet College, op. cit.; Tadie (1979), "A History of Drama at Gallaudet College," op. cit.

18. E. M. Gallaudet (1911), "A history of the Columbia Institution for the Deaf and Dumb," Speech to the Columbia Historical Society, January 17, 1911, Records of the Columbia Historical Society, Washington, DC, XV; Attwood, Gallaudet College, op. cit.

19. Gallaudet (1911), “A history,” op. cit, p. 6.

20. E. Peet (1949), "The building of Gallaudet," Gallaudet Alumni Bulletin, July, p. 3.

21. Tadie (1979), "A history of drama at Gallaudet College," op. cit.; "Interesting dedicatory exercises at the Columbia Institution” (1871), Daily Patriot, Washington, DC, July 30, p. 1.

22. Gallaudet (1911), “A history,” op. cit, p. 12.

23. E. M. Gallaudet (1882), "President Garfield's connection with the deaf-mute college" (pamphlet), Gibson Brothers, Washington, DC, pp. 7-11.

24. J. Gannon (Ed.) (1994), Gallaudet Almanac, Gallaudet Press, Washington, DC.; Gallaudet University Archives. Gallaudet College Catalogues, 1975-1976; Pulley (2003), "The sign language of fund raising," op. cit.

25. Tadie (1979), "A history of drama at Gallaudet College," op. cit.; Nina B. Van Oss (1953), “On Dr. Hall's long range plans," Gallaudet Alumni Bulletin, November.

26. Van Oss (1953), “On Dr. Hall's long range plans," p. 12, emphasis added.

27. Gallaudet University (2004), Office of Institutional Advancement. "Board of Associates Briefing Book," November 4.

28. Attwood (1964), Gallaudet College, op. cit.

29. United States Office of Education (1949), The Federal Government and the Higher Education of the Deaf: a progress report on the Columbia Institution for the Deaf, with proposals for action, United States Office of Education, Washington, DC.

30. Attwood (1964), Gallaudet College, op. cit.

31. R. N. Pacto (1969), "Reminiscences of Dr. Leonard M. Elstad," Buff and Blue, May 8, p. 2.

32 Historical Statistics of the United States (1975), The United States Government Printing Office, Washington DC, retrieved electronically from <http://www.westegg.com/inflation>.

33. J. R. Thelin (2004), A History of American Higher Education, The Johns Hopkins University Press, Baltimore, MD.

34. Gallaudet University (2004), Office of Budget, Administration and Finance, May 1.

35. Pulley (2003), "The sign language of fund raising," op. cit.; Cathy Sweet-Windham, interview with author, Washington, DC, November 3, 2004.
36. C. C. Garvin, Jr. (1978), Corporate Philanthropy: The Third Aspect of Social Responsibility, Council for Financial Aid to Education, New York.

37. Attwood, Attwood (1964), Gallaudet College, op. cit., pp. $38,44$.

38. Ibid., p. 45.

39. Cathy Sweet-Windham, interview.

40. N. M. Pusey (1978), American Higher Education, 1945-1970: A Personal Report, Harvard University Press, Cambridge, MA; Thelin (2004), A History of American Higher Education, op. cit.; W. B. Cook (1997), "Fund raising and the college presidency in an era of uncertainty: From 1975 to the present," Journal of Higher Education, 68, 1, pp. 53-86.

41. D. W. Breneman (1994), Liberal Arts Colleges: Thriving, Surviving, or Endangered? The Brookings Institution, Washington, DC.

42. David Armstrong, interview with author, Washington, DC, November 3, 2004

43. B. E. Brittingham and T. R. Pezzullo (1990), The Campus Green: Fund Raising in Higher Education. ASHE-ERIC higher Education Report No. 1, The George Washington University, School of Education and Human Development, Washington, DC.

44. Cathy Sweet-Windham, interview.

45. Gallaudet University (1997). Office of Institutional Advancement, "Grenzebach Feasibility Study review and update."

46. Ibid.

47. Gallaudet University (2004). Office of Institutional Advancement. "Board of Associates Briefing Book," op. cit; C. S. Hunter, E. B. Jones, and C. Boger (1999), "A study of the relationship between alumni giving and selected characteristics of alumni donors of Livingstone College, NC," Journal of Black Studies, 29, 4, pp. 523-39.

48. Pulley (2003), "The sign language of fund raising," op. cit.

49. Cathy Sweet-Windham, interview.

50. Lynne Murray, interview with author, Washington, DC, November 3, 2004.

51. Ibid.; M. Gasman and S. Anderson-Thompkins (2003), Fund Raising from Black-College Alumni: Successful Strategies for Supporting Alma Mater, Council for the Advancement and Support of Education, Washington, DC.

52. Lynne Murray, interview.

53. Council on Foundations (1999), Cultures of Caring, op. cit.

54. Gasman and Anderson-Thompkins (2003), Fund Raising from Black-College Alumni, op. cit.

55. Lynne Murray, interview, op. cit.

56. Ladd (2003), Understanding Deaf Culture, op. cit.

57. Ibid.; Lynne Murray, interview.

58. Cathy Sweet-Windham, interview. 
59. P. B. Chewning (1993), "The ultimate goal: Installing the volunteer and philanthropic ethic," in B. T. Todd (Ed.), Student Advancement Programs: Shaping Tomorrow's Alumni Leaders Today, Council for the Advancement and Support of Education, Washington, DC, pp. 147-8.

60. Lynne Murray, interview.

61. B. T. Todd (Ed.) (1993), Student Advancement Programs: Shaping Tomorrow's Alumni Leaders Today, Council for the Advancement and Support of Education, Washington, DC, p. iii.

62. Todd (1993), Student Advancement Programs, op. cit; Innes van Nostrand (1999), "Young alumni programming," in J. Feudo (Ed.), Alumni Relations: A Newcomer's Guide to Success, Council for the Advancement and Support of Education, Washington, DC, pp. 127-36.

63. Lynne Murray, interview.

64. Ibid.; L. H. Nakada (1993), "Student interns: Cultivating the next generation of advancement professionals," in B. T. Todd (Ed.), Student Advancement Programs: Shaping Tomorrow's Alumni Leaders Today, Council for the Advancement and Support of Education, Washington, DC, pp. 141-5.

65. Council for Aid to Education, "Voluntary Support of Education Survey-Data Miner," <http:// vse.cae.org>
66. American Association of Fundraising Counsel (2003), Giving USA 2003: The Annual Report on Philanthropy for the Year 2002, American Association of Fundraising Counsel, New York.

67. Council for Aid to Education, op. cit.

68. K. Kein (1994), Fundraising for Social Change, 3rd edn. Chardon Press, Inverness, CA.

69. American Association of Fundraising Counsel (2003), Giving USA 2003, op. cit., p. 116.

70. Gallaudet University (2004). Office of Institutional Advancement. "Board of Associates Briefing Book," op. cit.

71. M. S. Boyce (1992), "Fund-raising and market effectiveness at historically black colleges and universities," Ed.D. dissertation, State University of New York at Albany.

72. Cathy Sweet-Windham, interview.

73. Smith, Shue, Vest, and Villarreal (1999), Philanthropy in Communities of Color, op. cit.

74. Cathy Sweet-Windham, interview.

75. Ladd (2000), Understanding Deaf Culture, op. cit.

76. Cathy Sweet-Windham, interview. 
